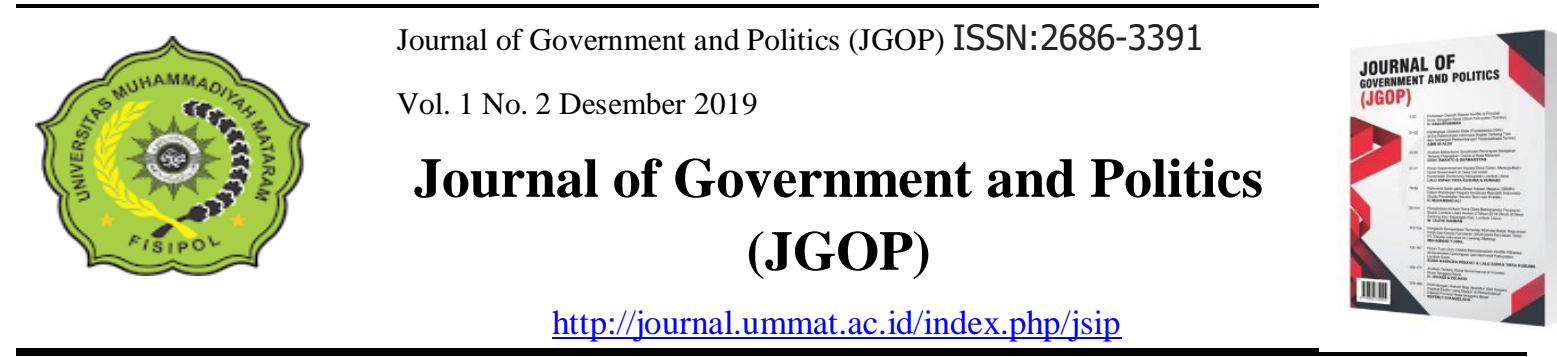

\title{
Analisis Peran Dinas Tenaga Kerja Kabupaten Lombok Barat Dalam Mengurangi Tingkat Pengangguran Di Kabupaten Lombak Barat Nusa Tenggara Barat
}

\author{
Hani Tria Prihatin ${ }^{1}$ Inka Nusamuda Pratama ${ }^{2}$ M.Ulfatul Akbar Jafar ${ }^{3}$ \\ ${ }^{123}$ Universitas Muhammadiyah Mataram
}

\begin{tabular}{l} 
InfoArtikel \\
\hline Sejarah Artikel: \\
Diterima: 25 Agustus 2019 \\
Disetujui: 20 Desember 2019 \\
Dipublikasikan : 20 \\
Desember 2019 \\
\hline
\end{tabular}

Kata Kunci :

Pengangguran; Dinas

Tenaga Kerja; Peran

\section{Abstrak}

Pengangguran adalah salah satu masalah yang sering terjadi di Indonesia, pengangguran menjadi salahsatu indikator penyebab kemiskinan di Indonesia. Penyerapan tenaga kerja yang minim tentu akan menyebabkan rendahnya penghasilan masyarakat Indonesia. Badan Pusat Statistik (BPS) merilis tingkat pengangguran terbuka (TPT) di Indonesia pada Februari 2018 mencapai $5,13 \%$, atau turun dari periode sama tahun sebelumnya, $5,33 \%$. Dari persentase tersebut, maka jumlah pengangguran di Indonesia saat ini mencapai 6,87 juta orang atau turun dari sebelumnya yang mencapai 7,01 juta orang.

Penelitian ini bertujuan untuk menganalisis Peran Dinas Tenaga Kerja Kabupaten Lombok Barat Dalam Mengurangi Tingkat Pengangguran Di Kabupaten Lombak Barat Nusa Tenggara Barat faktor penghambat pelaksanaan Peran Dinas Tenaga Kerja Kabupaten Lombok Barat Dalam Mengurangi Tingkat Pengangguran. Penelitian ini menggunakan metode deskriptif kualitatif dengan metode pengumpulan data observasi, dokumentasi dan wawancara.

Hasil penelitian ini ditemukan bahwa Peran Dinas Tenaga Kerja Kabupaten Lombok Barat Dalam Mengurangi Tingkat Pengangguran Dinas Tenaga kerja dan Transmigrasi Kabupaten Lombok Barat memberikan pelatihan untuk peningkatan skil dan keterampilan juga membuat kartu kuning untuk memudahkan para pencari kerja di perusahaan atau instansi pemerintah. Selain itu Dinas Tenaga kerja dan Transmigrasi Kabupaten Lombok Barat juga membangun jaringan dengan perusahaan swasta atau pebisnis agar bisa memperoleh lowongan pekerjaan serta menyebarluaskan informasi lowongan pekerjaan baik menggunakan media cetak maupun elektronik agar di ketahui oleh seluruh masyarakat Kabupaten Lombok Barat. 
Journal of Government and Politics (JGOP) Vol. 1 No. 2 Desember 2019 Hal. 125-136

Analysis of the Role of the West Lombok Regency Manpower Office in

Reducing Unemployment Rates in West Lombak Regency, West Nusa

Tenggara

Abstract

Unemployment is one of the problems that often occurs in Indonesia, unemployment is one indicator of the causes of poverty in Indonesia. Minimal absorption of labor will certainly cause low income for the people of Indonesia. The Central Statistics Agency (BPS) released the open unemployment rate (TPT) in Indonesia in February 2018 reaching 5.13\%, down from the same period the previous year, 5.33\%. From this percentage, the number of unemployed people in Indonesia currently reaches 6.87 million people, down from the previous 7.01 million people.

This study aims to analyze the Role of West Lombok Regency Manpower Office in Reducing Unemployment Rate in West Lombak Regency, West Nusa Tenggara, a limiting factor in the implementation of the Role of West Lombok Regency Manpower Office in Reducing Unemployment Rate. This research uses descriptive qualitative method with the method of collecting observation, documentation and interviews.

The results of this study found that the role of the West Lombok District Manpower Office in Reducing Unemployment Levels of the West Lombok District Manpower and Transmigration Office provided training to improve skills and skills and also made yellow cards to facilitate job seekers in companies or government agencies. In addition, the West Lombok Regency Manpower and Transmigration Agency also builds networks with private companies or businesses to be able to obtain job vacancies and disseminate information on job vacancies using both print and electronic media to be known by the entire West Lombok Regency community.

2019 Fakultas Ilmu Sosial Dan Ilmu Politik_Ummat 


\section{PENDAHULUAN}

Pengangguran adalah salah satu masalah yang sering terjadi di Indonesia, pengangguran menjadi salahsatu indikator penyebab kemiskinan di Indonesia. Penyerapan tenaga kerja yang minim tentu akan menyebabkan rendahnya penghasilan masyarakat Indonesia. Menurut Sadono Sukirno dalam Pitartono (2012), dalam standar pengertian yang sudah ditentukan secara internasional, yang dimaksudkan dengan pengangguran adalah seseorang yang sudah digolongkan dalam angkatan kerja yang secara aktif sedang mencari pekerjaan pada suatu tingkat upah tertentu, tetapi tidak memperoleh pekerjaan yang diinginkan.

Indonesia merupakan negara yang sedang berkembang yang pembangunan nasional dilaksanakan dalam rangka pembangunan manusia Indonesia seutuhnya dan pembangunan masyarakat yang sejahtera, adil dan makmur, yang merata baik materiil maupun spiritual berdasarkan Pancasila dan Undang-Undang Dasar Negara Republik Indonesia Nomor 13 Tahun 1945 tentang ketenagakerjaan. Ketenagakerjaan merupakan salah satu aspek dalam pembangunan.

Angkatan kerja adalah pelaku dalam proses pembangunan. Demi berhasilnya suatu pembangunan di perlukan angkatan kerja yang memadai, baik secara kualitas maupun kuantitas. Penciptaan kesempatan kerja adalah tujuan yang akan di capai dalam pembangunan, terutama dalam kondisi Indonesia yang mengalami surplus tenaga kerja. Masalah penciptaan lapangan pekerjaan merupakan salah satu tantangan bagi strategi dan kebijakan pembangunan agar terjadinya penyerapan tenaga kerja efektif dan menekan angka pengangguran di Indonesia.

Adanya UU Nomor 13 Tahun 2003 tentang ketenagakerjaan maka pemerintah berkewajiban dalam mengatasi masalah pengangguran ini. Dapat dilihat dalam pasal 1 menyatakan: (1) perencanaan tenaga kerja adalah proses penyusunan rencana ketenagakerjaan secara sistematis yang di jadikan dasar dan acuan dalam penyusunan kebijakan, strategi, dan pelaksanaan program pembangunan ketenagakerjaan yang berkesinambungan. (2) Kompetensi kerja adalah kemampuan kerja setiap individu yang mencakup aspek pengetahuan, keterampilan, dan sikap kerja yang sesuai dengan standar yang ditetapkan. (3) Pelayanan penempatan tenaga kerja adalah kegiatan untuk mempertemukan tenaga kerja dengan pemberi kerja, sehingga tenaga kerja dapat memperoleh pekerjaan yang sesuai dengan bakat, minat dan kemampuannya, dan pemberi 
kerja dapat memperoleh tenaga kerja yang sesuai dengan kebutuhannya. Dan juga pada pasal 39 pemerintah bertanggung jawab mengupayakan perluasan kesempatan kerja baik di dalam maupun di luar hubungan kerja. Semua kebijakan pemerintah baik pusat maupun daerah disetiap sektor diarah untuk mewujudkan perluasan kesempatan kerja baik diluar maupun maupun didalam hubungan kerja.

Badan Pusat Statistik (BPS) merilis tingkat pengangguran terbuka (TPT) di Indonesia pada Februari 2018 mencapai 5,13\%, atau turun dari periode sama tahun sebelumnya, 5,33\%. Dari persentase tersebut, maka jumlah pengangguran di Indonesia saat ini mencapai 6,87 juta orang atau turun dari sebelumnya yang mencapai 7,01 juta orang. Tingkat pengangguran di kota jauh lebih tinggi dibanding di desa. Pada Februari 2018, TPT di perkotaan sebesar 6,34\%, sementara TPT di wilayah pedesaan yang hanya sebesar 3,72\%. Jika dibandingkan periode yang sama tahun lalu, TPT di perkotaan dan di pedesaan masing-masing mengalami penurunan sebesar $0,16 \%$ dan $0,28 \%$.

Sementara jika dilihat dari tingkat pendidikannya, maka TPT terbesar berada pada level Sekolah Menengah Kejuruan (SMK) yang mencapai 8,92\%. Kemudian, setelah itu pada level Diploma I/II/III sebesar 7,92\%. Walaupun pada tahun 2018 angka pengangguran di Indonesia menurun menjadi 6,87 juta orang tetapi hal tersebut tetap memberikan pengaruh terhadap keadaan ekonomi masyarakat yang masih banyak di bawah garis kemiskinan.

Dengan adanya tingkat pengangguran di Indonesia yang masih cukup tinggi maka perlu ada kebijakan yang mendukung penyerapan tenaga kerja di Indonesia. Dalam hal ini Pemerintah mengeluarakan UU Nomor 13 Tahun 2003 tentang ketenagakerjaan maka pemerintah berkewajiban dalam mengatasi masalah pengangguran.

Indonesia yang menggunakan sistem pemerintah otonomi daerah berdasarkan Undang-Undang Nomor 23 Tahun 2014 tentang Otonomi daerah, agar pemerintah daerah bisa mengelola sumberdaya di daerah untuk kepentingan masyarakat. salah satunya adalah untuk mengurangi angka pengangguran. Dalam hal ini pemerintah daerah membentuk dinas tenaga kerja untuk memberikan pelatihan dan pelayanan pada angkatan kerja agar penyerapan tenaga kerja bisa berjalan efektif dan menekan angka pengangguran. Kabupaten Lombok Barat adalah sebuah Kabupaten di provinsi Nusa Tenggara Barat, Indonesia. Ibu kotanya ialah Gerung. Lombok Barat merupakan salah satu kabupaten yang sangat penting untuk Nusa Tenggara Barat, karena merupakan pusat pemerintahan di wilayah ini. 
Dalam perkembangan selanjutnya, berdasarkan Undang-Undang Nomor 26 Tahun 2008 tentang Pembentukan Kabupaten Lombok Utara, Kabupaten Lombok Barat bagian utara yaitu Kecamatan Pemenang, Tanjung, Gangga, Kayangan, dan Kecamatan Bayan adalah merupakan wilayah pemekaran dari Kabupaten Lombok Barat yang kemudian menjadi wilayah Pemerintahan Kabupaten Lombok Utara (KLU). Berdasarkan UndangUndang tersebut, maka dilantik Pejabat Bupati Kabupaten Lombok Utara (KLU) pada tanggal 30 Desember 2008, secara administrasi pembentukan Kabupaten Lombok Utara (KLU) sudah resmi, sehingga Kabupaten Lombok Barat yang sebelumnya membawahi 15 Kecamatan, menjadi 10 (sepuluh) Kecamatan, yakni :

1. Kecamatan Batu Layar

2. Kecamatan Gerung

3. Kecamatan Gunung Sari

4. Kecamatan Kediri

5. Kecamatan Kuripan

6. Kecamatan Labu Api

7. Kecamatan Lembar

8. Kecamatan Lingsar

9. Kecamatan Narmada

10.Kecamatan Sekotong

Dari data yang diperoleh mlah pengangguran terbuka di Kabupaten Lombok Barat setiap tahunnya terus mengalami penurunan. Badan Pusat Statistik (BPS) Lombok Barat mencatat tahun 2016, Lobar menjadi daerah kedua tingkat pengangguran terendah di NTB. Pengangguran terbuka di Lobar tahun 2016 mengalami penurunan 3,35 persen. Dari 297.000 angkatan kerja, sebanyak 276.000 sudah bekerja. Sayangnya, angka pengangguran yang menurun tersebut tidak sebanding dengan penduduk miskin.

Jumlah penduduk misikin di Lobar tahun 2016 mengalami kenaikan. Dari kisaran 17,11 persen atau mencapai 110.700 jiwa, naik kisaran 17,38 persen mencapai 113.300 jiwa. Artinya, pada tahun 2016 terdapat penambahan penduduk miskin sekitar 2.600 jiwa. Dari uraian permasalahan di latar belakang tersebut maka peneliti tertarik untuk melakukan penelitian terkait “Analisis Peran Dinas Tenaga Kerja Kabupaten Lombok Barat Dalam Mengurangi Tingkat Pengangguran Di Kabupaten Lombak Barat Nusa Tenggara Barat". 


\section{METODELOGI PENELITIAN}

Jenis penelitian dalam penelitian ini adalah jenis penelitian deskriptif kualitatif. Lokasi penelitian ini berada Dalam penelitian ini lokasi yang dipilih untuk penelitian adalah di Kantor Dinas Tenaga Kerja Kabupaten Lombok Barat. lokasi tersebut sangat strategis dalam melihat studi kasus dan permasalahan yang terjadi.

Dalam penelitian ini teknik pemilihan informan yang dipergunakan peneliti adalah purposive, untuk pemerintah karena sudah diketahui tugas pokok dan fungsi dalam pelaksanaan Peran Dinas Tenaga kerja Kabupaten Lombok Barat dalam mengatasi tingkat pengangguran. Adapaun informan dalam penelitian ini adalah:

1. Kepala Dinas Tenaga Kerja Kabupaten Lombok Barat

2. Staf atau Pegawai

3. Masyarakat

Sedangkan dalam Teknik analisa data dalam penelitian ini menggunakan model model miles and Huberman dalam Sugiyono (2015:91), dilakukan pada saat pengumpulan data berlangsung, dan setelah selesai pengumpulan data dalam periode tertentu. dimana model interaktif ini terdiri dari dari tiga hal utama, yaitu; (1) reduksi data; (2) penyajian data; dan (3) penarikan kesimpulan/verifikasi.

\section{HASIL DAN PEMBAHASAN}

1. Peran Dinas Tenaga Kerja Kabupaten Lombok Barat Dalam Mengurangi Tingkat Pengangguran di Provinsi Nusa Tenggara Barat

Peran Dinas Tenaga Kerja Dan Transmigrasi Kabupaten Lombok Barat Dalam Mengurangi Tingkat Pengangguran dapat di lihat berdasarkan peraturan pemerintah terkait Tugas Pokok dan Fungsi dari Dinas Tenaga Kerja Dinas Tenaga Kerja adalah kepanjangan dari (DISNAKER) Sesuai dengan Peraturan Pemerintah No. 41 Tahun 2007 tentang organisasi perangkat daerah bahwa untuk penyelengaraan pemerintah daerah, kepala daerah perlu dibantu oleh perangkat daerah yang dapat menyelenggarakan seluruh urusan pemerintah yang dilaksanakan oleh pemerintah daerah oleh karena itulah dibutuhkan dinas daerah yang berperan dalam menyelenggarakan fungsi.

Seperti yang di ungkapkan oleh Kepala Bidang Ketenagakerjaan Dinas Tenaga kerja dan Transmigrasi Kabupaten Lombok Barat bahwa: "Dinas Tenaga kerja dan Transmigrasi Kabupaten Lombok Tengah untuk mengurangi tingkat pengangguran kami 
melaksanakan kegiatan pelatihan kerja dan keterampilan dalam bentuk pemberian kursus sesuai dengan minat dan bakat dari calon tenaga kerja kurang lebih 1-3 bulan sesuai dengan model dan bidang pelatihan misalnya kursus memperbaiki alat elektronik itu bisa 2-3 bulan dan akan di berikan sertifikat pendamping kompetensi agar bisa digunakan untuk melamar pekerjaan" (hasil wawancara 2018).

Dari wawancara diatas dapat diketahui bahwa Dinas Tenaga Kerja dan Transmigrasi Kabupaten Lombok Barat berupaya melakukan pelatihan skill atau keahlian bagi para pencari kerja agar dapat bekerja sesuai dengan yang dibutuhkan oleh pasar kerja dan juga agar para pencari kerja dapat mandiri dalam mencari pekerjaan dengan kemampuan atau skill yang mereka miliki. Pelatihan skill atau kemampuan ini rutin di lakukan oleh Dinas Tenaga Kerja Kabupaten Lombok Barat setiap tahunnya agar dapat membantu mengatasi masalah pengangguran di Kabupaten Lombok Barat.

Pelatihan terhadap tenaga kerja adalah untuk memperbaiki performa pekerja dalam suatu pekerjaan tertentu yang sedang menjadi tanggung jawab atau suatu pekerjaan yang ada kaitannya dengan pekerjan. Supaya efektif pelatihan pelatihan biasanya harus mencakup pengalaman belajar, aktivitas- aktivitas yang terencana, serta didesain sebagai jawaban atas kebutuhan- kebutuhan yang berhasil diidentifikasikan. Secara ideal pelatihan harus dibuat untuk mewujudkan tujuantujuan yang pada waktu bersamaan juga mewujudkan tujuan dari pada para pekerja secara pribadi.

Hasil dari kegiatan pelatihan itu sendiri sangat berdampak baik langsung terhadap tenaga kerja yang mendapat pelatihan, masyarakat yang mendapatkan bekal pelatihan yang dilakukan DISNAKER pasti terdapat perubahan dimana yang mendapat pelatihan ini ada yang anak sekolahan atau masyarakat. Dan dari pelatihan tersebut pastilah terdapat keahlian yang mereka dapatkan, mereka bisa bekerja membuka usaha sendiri atau bisa saja masyarakat yang telah mendapatkan pelatihan mereka ikut bekerja dengan orang lain. Beberapa jenis pelatihan yang dilakukan oleh Dinas Tenaga kerja. Untuk membuat para calon tenaga kerja atau tenaga kerja menguasai atau mempunyai pengetahuan lebih tentu tidak cukup apabila dibekali hanya dengan pelatihan.

Jadi dapat disimpulkan bahwa peran Dinas Tenaga Kerja dan Transmigrasi Kabupaten Lombok Barat adalah sebagai berikut:

1. Memberikan pelatihan dan keterampilan pada para pencari kerja agar memilik keahlian dan skil yang dibutuhkan oleh lapangan pekerjaan saat ini 
2. Membangun jaringan dengan investor atau penanam modal agar mudah mendapatkan lowongan pekerjaan

3. Menyebarluaskan informasi kepada masyarakat Kabupaten Lombok Barat melalui media cetak dan elektronik

4. Membuat kartu kuning atau kartu pencari kerja.

Perluasan kerja yang dilakukan Dinas Tenaga Kerja (DISNAKER) dengan program-programnya yaitu program padat karya sangat dapat membantu orang untuk memiliki pekerjan agar bisa mendapatkan atau memperoleh pengasilan yang lebih.

2. Faktor Penghambat Peran Dinas Tenaga Kerja dan Transmigrasi Kabupaten Lombok Barat dalam mengurangi tingkat pengangguran

\section{Sumberdaya Manusia}

Sumber daya manusia atau pegawai Dinas Tenaga Kerja Kabupaten Lombok Barat merupakan unsur penting bagi suatu dinas untuk memaksimalkan kinerja dan produktivitas terkait dalam hal ini. Karena unsur sumber daya manusia yang dalam hal ini adalah para pegawai untuk membantu menjalankan tugas dan fungsinya.

Komponen sumber daya ini meliputi jumlah staf, keahlian para pelaksana, komunikasi yang relevan dan cukup untuk melaksanakan pencarian lowongan pekerjaan ke perusahaan dan penemuan sumber- sumber terkait dalam pelaksanaan program, adanya kewenangan yang menjamin bahwa program dapat di arahkan kepada sebagaimana yang di harapkan, serta adanya fasilitas-fasilitas pendukung yang dapat dipakai untuk melakukan kegiatan program seperti dana, sarana dan prasarana.

Jika jumlah staf/pegawai pelaksanaan penyebarluasan informasi lowongan pekerjaan dan pencarian lowongan pekerjaan terbatas, maka hal yang harus dilakukan adalah meningkatkan kemampuan para pelaksana untuk melakukan program. Untuk ini perlu adanya manajemen sumber daya yang baik agar dapat meningkatkan kinerja dalam kegiatan mengatasi jumlah pengangguran Kabupaten Lombok Barat.

Ada dua bentuk informasi, yaitu informasi mengenai bagaimana cara menyelesaikan kebijakan/program serta bagi pelaksana harus mengetahui tindakan apa yang harus dilakukan dan informasi tentang pendukung kepatuhan kepada peraturan perundang-undangan.

2. Sarana dan Prasarana 
Secara umum sarana dan prasarana adalah alat penunjang keberhasilan suatu proses upaya yang dilakukan dilayanan public, karena apabila kedua hal ini tidak tersedia maka semua kegiatan yang dilakukan tidak akan dapa mencapai hasil yang harapkan sesuai dengan rencana. Kekurangan sarana dan prasarana akan menghambat strategi yang telah direncanakan. Sarana dan prasarana yang belum tersedia yaitu gedung Balai Pelatihan Kerja yang dapat menampung kegiatan pelatihan. Dan juga komputer yang merupakan salah satu komponen sarana dan prasarana dalam melaksanakan proses pembuatan kartu kuning yang urgensinya sangat dominan dalam upaya mengatasi masalah pengangguran di Kabupaten Lombok Barat dengan mengetahui berapa banyak yang mendaftarkan diri sebagai pencari kerja. Pengadaan sarana dan prasarana penunjang kegiatan pelatihan dan keterampilan harus terus diupayakan oleh Dinas Tenaga Kerja dan Transmigrasi Kabupaten Lombok Barat, agar pelaksanaannya dapat berjalan secara optimal. Apabila sarana dan prasarana masih kurang, tentu akan menghambat proses pelatihan yang dilaksanakan sehingga tidak berjalan secara optimal.

\section{Komunikasi}

Komunikasi sangat penting dalam pencarian lowongan pekerjaan karena dengan adanya komunikasi akan mudah mendapatkan informasi- informasi yang di perlukan, dan juga banyak komunikasi memperbesar peluang untuk mendapatkan lowongan pekerjaan.

Dalam hal ini, Dinas Tenaga Kerja dan Transmigrasi Kabupaten Lombok Barat harus memahami betul terkai tugas dan kewenangannya untuk mengatasi pengangguran di Kabupaten Lombok Barat, selain itu pemberian sosialisasi kepada masyarakat Kabupaten Lombok Barat harus terus ditingkatkan terkait pentingnya mengikuti kegiatan pelatihan peningkatan skil dan keterampilan yang di adakan oleh Dinas Tenaga kerja dan Transmigrasi Kabupaten Lombok Barat.

\section{Anggaran yang di miliki}

Keterbatasan Anggaran tentu masih menjadi salah satu faktor penghambat pelakanaan peran Dinas Tenaga Kerja dan Transmigrasi Kabupaten Lombok Barat karena anggaran yang diperoleh untuk melaksanakan kegiatan pelatihan tenaga kerja hanya bersumber dari anggaran pendapatan belanja daerah saja. Sehingga pengelolaan anggaran untuk kegiatan pelatihan kerja dan peningkatan skil masyarakat Kabupaten Lombok Barat harus di kelola secara efektif dan efesien memilih kegiatan atau bidang yang sangat diperlukan oleh maasyarakat untuk memperoleh pekerjaan. Jika ada anggaran secara terus menerus tidak mungkin tingkat pengangguran bisa meningkat di karenakan Dinas Tenaga 
Kerja sebagai instansi yang memberika pelatihan terhadap calon tenaga kerja akan tetap memberikan pelatihan kepada tenaga kerja yang ada di Kabupaten Lombok Barat sehingga bisa memperoleh pengetahuan dan skil sesuai dengan kebutuhan lapangan pekerjaan saat ini.

\section{KESIMPULAN}

Peran Dinas Tenaga Kerja Dan Transmigrasi Kabupaten Lombok Barat Dalam Mengurangi Tingkat Pengangguran dapat di lihat berdasarkan peraturan pemerintah terkait Tugas Pokok dan Fungsi dari Dinas Tenaga Kerja Dinas Tenaga Kerja adalah kepanjangan dari (DISNAKER) Sesuai dengan Peraturan Pemerintah No. 41 Tahun 2007 tentang organisasi perangkat daerah bahwa untuk penyelengaraan pemerintah daerah, kepala daerah perlu dibantu oleh perangkat daerah yang dapat menyelenggarakan seluruh urusan pemerintah yang dilaksanakan oleh pemerintah daerah oleh karna itulah dibutuhkan dinas daerah yang berperan dalam menyelenggarakan fungsi. Perumusan kebijakan teknis sesuai dengan lingkup tugasnya, pemberian izin dan pelaksanaan pelayanan umum, serta pembinaan pelaksanaan tugas sesuai dengan lingkup tugasnya.

Dinas Tenaga Kerja Dan Transmigrasi Kabupaten Lombok Barat Dalam Mengurangi Tingkat Pengangguran melaksanakan peran sesuai dengan tugas pokok dan fungsinya di bidang ketenagakerjaan yaitu melaksanakan dan mempersiapkan tenaga kerja yang unggul dalam bentuk pemberian pelatihan dan keterampilan pada calon tenaga kerja agar bisa di tempatkan pada pekerjaan sesuai dengan kemampuan dan keahlian. Baik penempatan dalam negeri maupun menjadi tenaga kerja Indonesia di luar negeri, berdasarkan peraturan pemerintah Kabupaten Lombok Barat.

Dinas Tenaga kerja dan Transmigrasi Kabupaten Lombok Barat memberikan pelatihan untuk peningkatan skil dan keterampilan juga membuat kartu kuning untuk memudahkan para pencari kerja di perusahaan atau instansi pemerintah. Selain itu Dinas Tenaga kerja dan Transmigrasi Kabupaten Lombok Barat juga membangun jaringan dengan perusahaan swasta atau pebisnis agar bisa memperoleh lowongan pekerjaan serta menyebarluaskan informasi lowongan pekerjaan baik menggunakan media cetak maupun elektronik agar di ketahui oleh seluruh masyarakat Kabupaten Lombok Barat. 
Jadi dapat disimpulkan bahwa peran Dinas Tenaga Kerja dan Transmigrasi Kabupaten Lombok Barat adalah sebagai berikut:

a. Memberikan pelatihan dan keterampilan pada para pencari kerja agar memilik keahlian dan skil yang dibutuhkan oleh lapangan pekerjaan saat ini

b. Membangun jaringan dengan investor atau penanam modal agar mudah mendapatkan lowongan pekerjaan

c. Menyebarluaskan informasi kepada masyarakat Kabupaten Lombok Barat melalui media cetak dan elektronik

d. Membuat kartu kuning atau kartu pencari kerja.

\section{DAFTAR PUSTAKA}

Jakarta. Sitorus, M. 2006. Sosiologi 2. Gelora Aksara. Jakarta.

Jeffri Chandra Irvanto dkk, (2017) “Peran Dinas Tenaga Kerja (Disnaker) Dalam Mengurangi Tingkat Pengangguran Kota Samarinda” Unmul.

Pitartono, (2012). Analisis Tingkat Pengangguran Di Jawa Tengah tahun 1997- 2010.

Riyadi. 2002. Perencanaan Pembangunan Daerah Strategi Mengendalikan Potensi Dalam Mewujudkan Otonomi Daerah. Gramedia. Jakarta.

Sastrohadiwiryo, Siswanto. 2005. Manajemen Tenaga Kerja IndonesiaPendekatan Administratif dan Oprasional, Cetakan Ketiga, Bumi Aksara,

Soekanto, soejono 2001. Sosiologi Sebagai Pengantar. Jakarta : PT Raja Grafindo Persada.

Sugiyono Prof. Dr. 2010. Metode Penelitian Pendidikan Pendekatann Kuantitatif, Kualitatif dan R \& D. Bandung: Cv. Alfa Beta.

Sugiyono. 2005. Memahami Penelitian Kualitatif. Alfabeta: Bandung. Thoha, Miftah. 2003. Pembinaan Organisasi. Rajawali pers: Jakarta. Zulkarnain, S. (2008). Hubungan Kontrol Diri dengan Kreativitas Pekerja.

Dokumen-dokumen:

Peraturan Pemerintah No. 41 Tahun 2007 tentang organisasi perangkat daerah bahwa untuk penyelengaraan pemerintah daerah

Undang-Undang Nomor 23 Tahun 2014 tentang Sistem Otonomi Daerah http://disnaker.lombokbaratkab.go.id/_diakses 2 november 2018

http://lombokpost.net/2017/02/09/pengangguran-lobar-menurun/ 
Journal of Government and Politics (JGOP) Vol. 1 No. 2 Desember 2019 Hal. 125-136

https://lombokbaratkab.bps.go.id/subject/6/tenagakerja.html\#subjekViewTa b3

https://id.wikipedia.org/wiki/Kabupaten_Lombok_Barat Diakses tanggal 28

Oktober 2018.

http://lombokbaratkab.go.id/sekilas-lobar/visi-misi/diakses 30 oktober 2018 
Journal of Government and Politics (JGOP) Vol. 2 No. 1 Juli 2020 Hal. 112-124 